\title{
Book review: Luiza Wojnicz, Civilian Missions of the European Union in the process of Europeanisation ad extra, Wydawnictwo Adam Marszałek, Toruń 2019, pp. 490
}

\section{Magdalena Pilipczuk ${ }^{1}$}

DOI: https://doi.org/10.15804/rop2021211

The monograph "Civil missions of the European Union in the process of Europeanisation ad extra" is the result of research conducted by Dr Luiza Wojnicz (D.Sc.) on European security issues, including primarily terrorism and the policy of the European Union, therefore the issue - in the legal and institutional sphere - of external actions of the European Union (cooperation with third countries), the security of the European Union and its member states understood theoretically and functionally. However, the main subject of the Author's monograph is the issues of theoretical and practical application of the instruments of the Common Security and Defence Policy in the EU's expeditionary policy. The Author devotes a lot of space to an in-depth analysis of the collected material, combining civil missions as a distinguishing feature of the

1 Graduate student at the Institute of Political Science and European Studies University of Szczecin, e-mail: magdalenapilipczuk1@gmail.com.
CSDP with the concept of Europeanisation, which is identified with the internal impact of the EU. Dr Luiza Wojnicz (D.Sc.) shows that Europeanisation as a process does not have to relate strictly to the area of the European Union. This process can be used just as well outside the EU.

The reviewed monograph consists of an introduction, five chapters, conclusion, bibliography, list of abbreviations, list of diagrams and tables, and list of charts.

In the Introduction, Ms Luiza Wojnicz outlines a historical outline aimed at establishing and focusing on civilian missions, which are a tool of the European Union's expeditionary policy. She formulates a hypothesis in it, sets goals and subjects it to a temporal caesura. In the case of this monograph, the field of research is the impact of the expeditionary policy on third countries and the indication of changes that have occurred in them as a result of this impact. The Author points to Europeanisation as a tool due to its multi-functionality. The goal that Ms. Wojnicz set herself in this work was 
to verify the effects that may be brought by combining Europeanisation (identified more with internal influence) with the external dimension of the Common Security and Defence Policy. The adopted timeline is the years 2003-2014. During that time, the European Union carried out the following civilian missions in the following regions of the world: Bosnia and Herzegovina, Macedonia, Kinshasa and the Democratic Republic of Congo, in South Sudan, Guinea-Bissau, Georgia, Iraq and Indonesia. As a specific goal, it sets "multifaceted and multidimensional verification of the impact of the ad extra Europeanisation on security management in third countries at various levels, taking into account quantitative and qualitative components of the ad extra Europeanisation" (Introduction, p. 13). This is an unusual approach to the issue, as we usually focus on solving emerging crises, that is, we deal with the effects of existing problems, instead of studying the measurement of absorbed European legal standards and values. The Author explains the key terms concerning the monograph, which are the process of Europeanisation and its external trajectory, and introduces two new concepts - expeditionary policy and acquis expeditionnaire, thus defining the Common Security and Defence Policy acquis. Ms Luiza Wojnicz bases her research on the analysis of indicators of Europeanisation in quantitative and qualitative terms. The monograph consti- tutes a complete whole of the discussed problem, as it contains theoretical and pragmatic issues.

In her monograph, she also precisely explains the term Europeanisation and its meaning in the internal, i.e. EU, application. She also emphasises that this process can be successfully used in external applications, pointing to its external trajectory. And it is this external trajectory that has been used to investigate the absorbability of European standards and values in third countries through civilian missions.

After explaining the issues related to the Europeanisation process, Ms Wojnicz discusses the beginnings of the Common Security and Defence Policy (CSDP), emphasising its expeditionary nature. There is no shortage of legal acts. Political Science and European Studies theories, which are the foundations on which the CSDP was founded, deserve attention.

The Author also explains the conceptual framework of CSDP in the context of soft power, normative power, smart power and civilian power. This is an interesting complement to the theoretical aspects in the context of the discussed CSDP. The monograph also includes the geographical dislocation of EU civilian missions, as well as the procedure for appointing and sending these missions. Due to the purpose of the work, it is important to indicate the assumptions of civilian missions, i.e. their goals and tasks, because they helped the Author verify the scope of their absorbability. 
The monograph "Civil missions of the civil missions of the Common Security European Union in the process of ad and Defence Policy. The monograph is extra Europeanisation" is the result of interesting and objective. The purpose a diligent analysis of the rich bibliography. of its creation was not to evaluate the EU It is additionally supported by charts and civilian missions, although the Author tables, which clearly shows the results of emphasises the awareness of the problems research on the impact of Europeanisation on third countries and the effectiveness of civil expeditionary policy in the areas that were implemented in the years 2003-2014.

Summing up, the monograph of Ms Luiza Wojnicz should be considered a significant contribution to the theoretical aspect of the issues related to the that occurred during the implementation of the discussed missions, but to examine what have been achieved thanks to them and how much have been achieved, taking into account various circumstances. Let us hope that Ms Luiza Wojnicz will want to deepen her research in this area, extending it to new issues. 